\title{
Analysis of dynamics of changes and efficiency of implementation and development of the project management system in Russia
}

\author{
Oleg Markov ${ }^{1}$, Mikhail Loginov², and Aleksey Ruchkin ${ }^{3, *}$ \\ ${ }^{1}$ Presidential Academy of National Economy and Public Administration, Department of Economy and \\ Management, 620144 66, $8^{\text {th }}$ street, Yekaterinburg, Russia \\ ${ }^{2}$ Ural state University of Economics, Department of Finance, money circulation and credit, 620144 \\ $62 / 458^{\text {th }}$ March/Narodnoy Voly, Yekaterinburg, Russia \\ ${ }^{3}$ Ural state agrarian University, Institute of Economics, Finance and Management, 62007542 Karl \\ Liebknecht street, Yekaterinburg, Russia
}

\begin{abstract}
The authors present the theoretical and methodological foundations of building project management systems in Russia. Study and evaluate the effectiveness of domestic project management experience in Russian Federation. The authors reviewed the process of dynamics of changes in the implementation of project management in Russia. We evaluated the previously existing organizational structure, with the current one. Formed in accordance with the Decree of Government of Russian Federation of 31 October 2018 No. 1288 "On the organization of project activities in Government of Russian Federation", identified problems and gave practical recommendations. The object of research in the article is the system of project management in the state authorities of Russian Federation. The subject of the research is the methodology of project management system implementation in Russia. The purpose of the research is to analyze changes and methods of implementing project management systems in Russian Federation. Efficiency assessment and author's suggestions for improving the project management system in Russia.
\end{abstract}

\section{Introduction}

Project management in Russia took root in 1990, when the Soviet government decided to create a non-profit partnership "project management Association "SOVNET", whose President was elected Vladimir Ivanovich Voropaev. It was he who made a significant contribution to the implementation and development of project management in the Russian Federation. Since 1991, the Association joined the international project management Association IPMA, and in 1992, a bilateral cooperation agreement was signed with the most important and numerous American project management Association PMA. Until 2004. cooperation agreements were signed with almost all project-oriented countries of the world [1].

\footnotetext{
*Corresponding author: alexeyruchkin87@gmail.com
} 
Representatives of business and large state corporations were the first to respond to the development of project management in Russia. Who is more interested in the project approach, because project management solves the most important tasks of business management, such as:

- Transparency of business processes;

- Comprehensive time management;

- Effective management of the revenue and expenditure budget and the cash flow budget;

- Experienced risk management;

- Rational management of the use of inventory and other resources intended for project implementation;

- Improving the effectiveness of strategic planning, etc.

The modern development of management in Russia has led to a logical result-the introduction of project management tools in the activities of all market participants [2].

According to the report of the American Institute of project management (PMI - Project Management Institute) for 2018, an average of $9.9 \%$ of the approved budgets of completed projects are spent for other purposes. Even leading organizations with a high rating of project management maturity on average complete only about 80 percent of projects on time and within budget [3]. All this information highlights the relevance of new research and development of modern approaches in project management.

Russian and foreign scientists are constantly working to improve approaches to project management in order to meet modern requirements.

In recent years, project management has been actively implemented in public authorities at all levels.

Research in the field of project management in public authorities has become the subject of numerous Russian and foreign scientists, experts and practitioners.

The greatest contribution to the theoretical and practical work on the implementation and development of project management systems was made by such authors as: V. I. Voropaev [4], A.V. Polkovnikov, M. F. Dubovik [5], V. Bogdanov [6], R. A. Nugaybekov [7], G. Jia [8], O. N. Safonova, E. A. Anchikhrov [9], S. A. Kozhevnikov [10] and others. Researchers K. Muszyńska [11], Sh. Nikkhou [12], Yu.Strojny [13], pay special attention to the implementation of state projects due to the specifics of regulatory regulation, the scale of projects and a large number of stakeholders.

\section{Method}

The research methodology consists of a systematic analysis of normative and regulatory documentation on project management, as well as theoretical and practical aspects of the implementation and development of project management systems in the state authorities of Russian Federation.

The study includes:

- Study and analysis of scientific literature on the implementation and development of project management;

- Analysis of methods for implementing project management systems in the state authorities of Russian Federation;

- Monitoring changes and developments in the regulatory and regulatory documentation for project management in Russia.

- Assessment of the effectiveness of implementation of Government Resolutions (Decree's) by federal and regional executive authorities. 


\section{Study detail and result}

The first regulatory documents on project management at the national level appeared in 2011, namely:

- GOST (State standard) R 54869-2011 "Project management. Project management requirements";

- GOST (State standard) R 54870-2011 "Project management. Project portfolio management requirements";

- GOST (State standard) R 54871-2011 "Project management. Requirements for the management program".

All of the above standards were limited only to basic concepts, terms and definitions and did not contain any methodology for project activities.

However, in 2013. the Order of the Ministry of communications of the Russian Federation dated 24 April 2013 No. 96 "On approval of methodological recommendations for the organization of the project management system for informatization activities in state authorities" was issued, and a year later a new national standard GOST R ISO 21500 - 2014 "Guide to project management" appeared. It was supplemented by Methodological recommendations on the implementation of project management in the executive authority, as well as an Appendix to the Order of the Ministry of economic development of the Russian Federation No. 26R-AU dated 14 April 2014 "On approval of methodological recommendations for the implementation of project management in executive authorities".

In 2015, Russian President Vladimir Putin, in his address to the Federal Assembly, spoke about the need to introduce project management tools in state authorities [14]. As a result, 2016 became a key year in the development of project management in public authorities.

At this time, a decree of the government of the Russian Federation dated 15 October 2016 was issued. No. 1050 "On the organization of project activities in Government of Russian Federation" in accordance with which the structure of management of strategic project activities at the federal level is defined. This structure includes the permanent institutions of project management.

Figure 1 shows the organizational and functional scheme for managing priority projects and programs in Russian Federation. The diagram shows the structure of project management at the level of Senior management in Russian Federation, as well as the organization of project management offices at the level of state authorities. The advantages of the national project management model proposed by the state include the first project management tools used together: project offices, information support, project lifecycle in multi-project management, etc. [15]. 


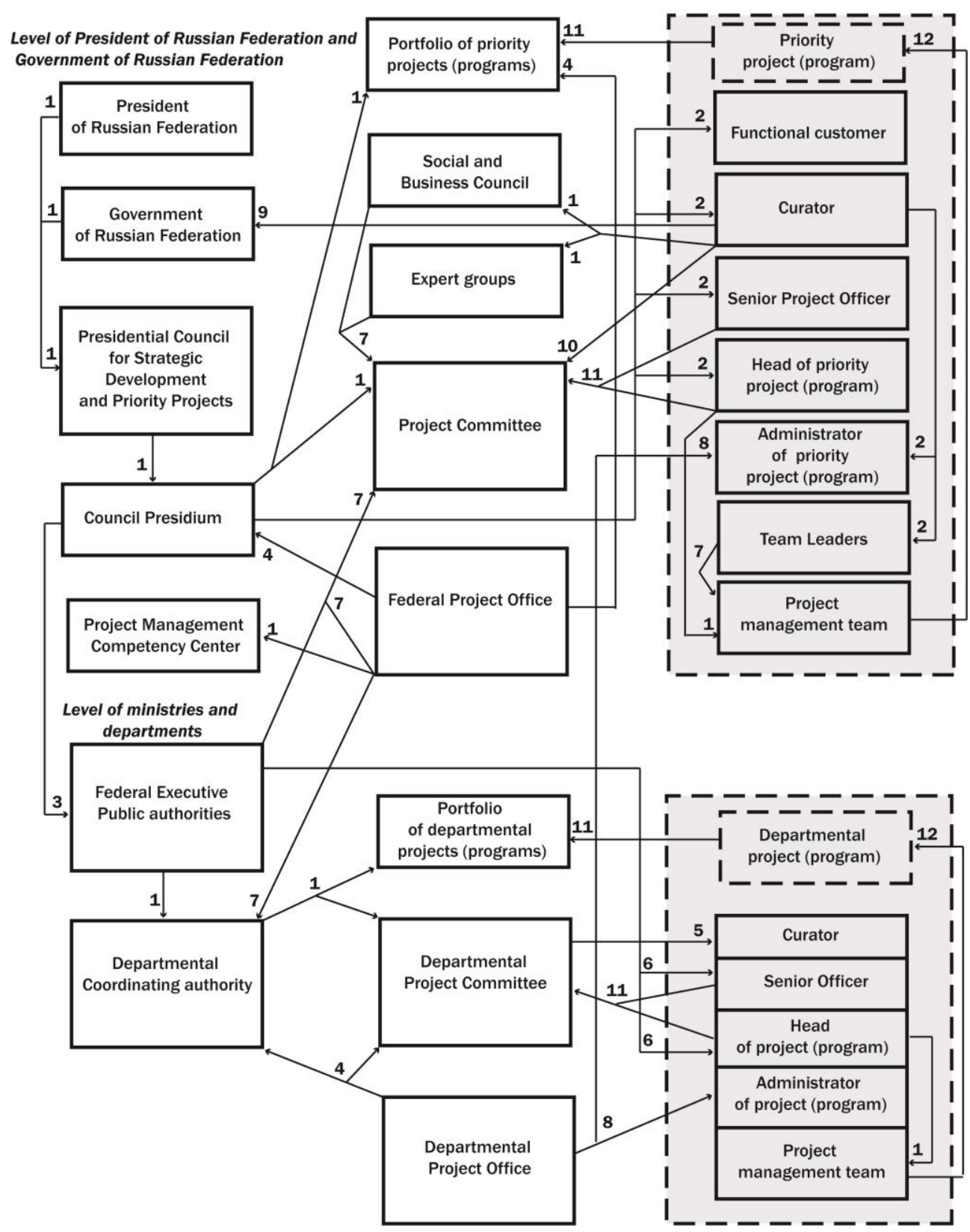

Fig. 1. Organizational and functional scheme for managing priority projects (programs) [Compiled by the authors]

Designations:

1 - forms; 2 - appoints; 3 - coordinates activities; 4 - provides activity; 5 - offers; 6 - claims; 7 includes a representative; 8 - provides (implements) functions; 9 - submits draft regulatory legal acts; 10 - directs; 11 - includes; 12 - implementation of the project.

These rather large-scale, project-oriented structural changes did not give the expected result of implementing and developing the project management system in the state authorities of Russian Federation. The key tasks of implementing project management were 
not solved, from improving the efficiency of using budget funds, improving the quality of project resource planning, developing basic tools to achieve project goals, to forming a system for motivating project personnel. The lack of effective motivation in any management system will never give a positive result in achieving goals [16].

In order to assess the effectiveness, the project management system implementation in public authorities was monitored, which was attended by 13 federal executive authorities and 16 regional executive authorities [17] according to the following criteria:

- Development and approval of a regulatory and methodological framework for project management;

- Creation of project committees;

- Establishment of project offices;

- The use of effective motivation of the project personnel.

The results of which showed the following (table 1).

Table 1. Results of monitoring the implementation of project management tools in the Federal and regional authorities of Russian Federation [Compiled by the authors]

\begin{tabular}{|l|c|c|}
\hline \multicolumn{1}{|c|}{ Indicators } & $\begin{array}{c}\text { Performance of } \\
\text { Federal Executive } \\
\text { authorities in \% }\end{array}$ & $\begin{array}{c}\text { Performance of } \\
\text { Regional Executive } \\
\text { authorities in \% }\end{array}$ \\
\hline $\begin{array}{l}\text { Development and approval of the regulatory } \\
\text { and methodological framework for project } \\
\text { management }\end{array}$ & 13,4 & 12,5 \\
\hline The establishment of project committees & 23,1 & 18,7 \\
\hline The establishment of project offices & 38,5 & 31,2 \\
\hline $\begin{array}{l}\text { Using effective motivation of project } \\
\text { personnel }\end{array}$ & 0 & 25 \\
\hline
\end{tabular}

According to the table, it can be concluded that federal and regional authorities are not interested in implementing a project management system in their departments.

However, failure to comply with the orders of President and Government of Russia set out in the decree of Government of Russian Federation of 15 October 2016. No. 1050 "On the organization of project activities in Government of Russian Federation" led to the creation of a new guidance document.

Today, the organization of national project activities in Russia is regulated by Decree of Government of Russian Federation No. 1288 of 31 October 2018 "On the organization of project activities in Government of Russian Federation". With its introduction decree of the government of the Russian Federation of 15 October 2016 No. 1050 "On the organization of project activities in Government of Russian Federation" has lost its force. This resolution approved the regulation on the organization of project activities in the government at all levels. This resolution regulates the implementation of the project approach in the main areas of Russia's strategic development using the automated multi-project management information system (AISMU) [18; 19].

Figure 2 (compiled by the authors) shows the organizational and functional scheme of project and program management in Russian Federation. The diagram shows the structure of project management at the level of Senior management in Russian Federation, as well as the organization of project management offices at the level of state authorities. The advantages of the national project management model proposed by the state include the first 
project management tools used together: project offices, information support, project lifecycle in multi-project management, etc.

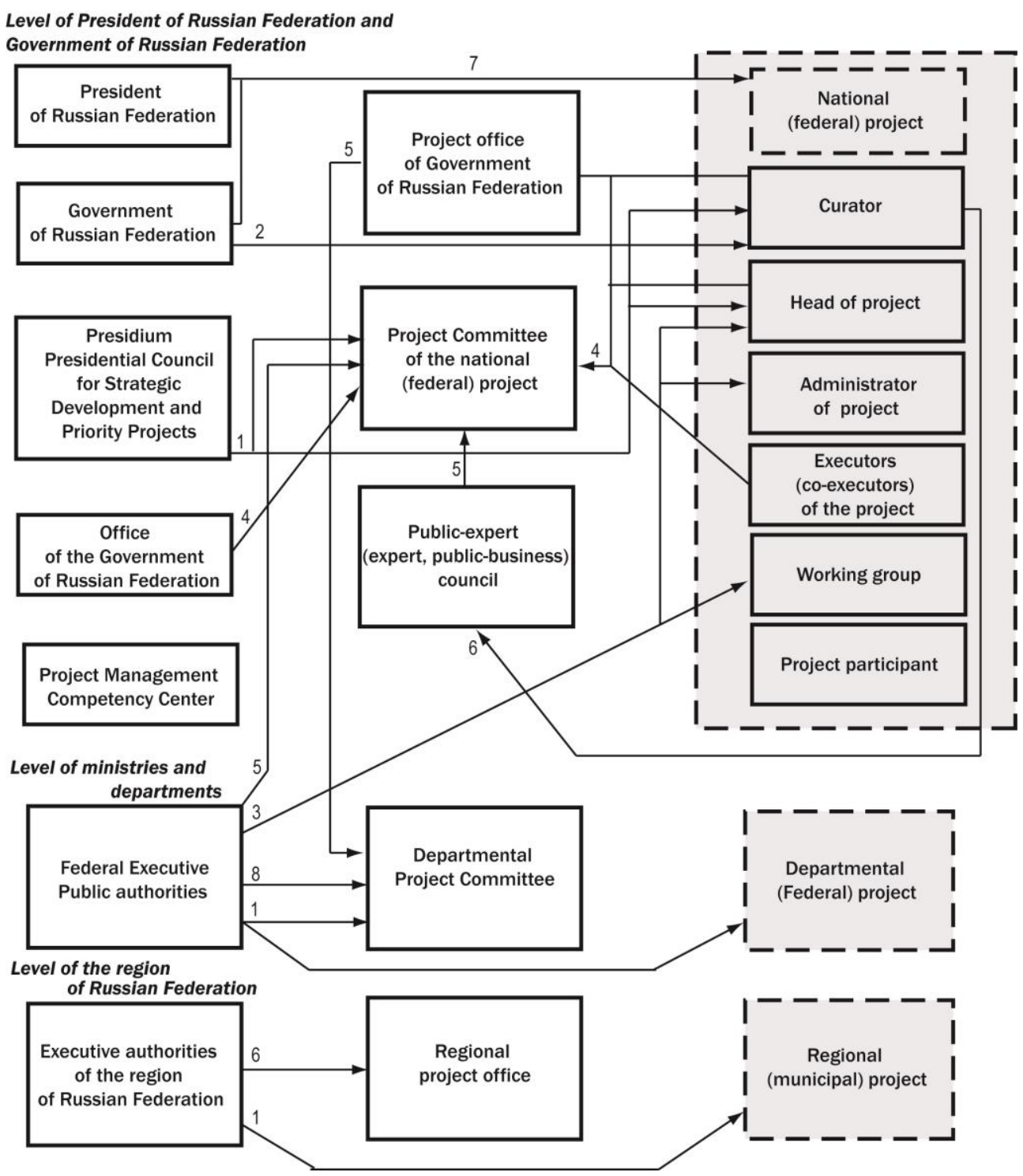

Fig. 2. Organizational and functional structure of the organization of project activities in the state authorities of the Russian Federation [Compiled by the authors]

Designations:

1 - approves; 2 - is a member of the Government of Russian Federation; 3 - head or Deputy; 4 includes a representative; 5 - includes a representative; 6 - forms a representative; 7 - the national project is approved by President of Russian Federation, the Federal project is approved by President of Russian Federation, Government of Russian Federation; 8 - Oversees the deputy- head of the Federal authority.

Of organizational and functional structure of organization of project activities in the state authorities of the Russian Federation, based on the newly entered into force, the government of the Russian Federation from 31 October 2018 No. 1288 "About the organization of project activities the government of the Russian Federation", it is clear that 
abolished the mention of the portfolio of priority projects (programs) and the portfolio of departmental projects (programs).

Expert groups were also abolished: senior officials, heads of working bodies, departmental coordination bodies, and functional customers, as well as the project management team.

New project management subjects are included:

- Apparatus of Government of Russian Federation;

- Project office of the subject;

- National and Federal project working group;

- Project office of Government of Russian Federation (in the now - invalid decree No. 1055-Federal project office).

In resolution No. 1288 the concept of project is classified into the following levels

priorities with appropriate definitions:

1. national project - a project (program) that ensures the achievement of goals and targets, and the fulfillment of tasks defined by the decree of the President of the Russian Federation of 7 May 2018. No. 204 "On national goals and strategic objectives of the development of Russian Federation for the period up to 2024", as well as, if necessary, achieving additional indicators and performing additional tasks on behalf and (or) instructions of President, the order of Prime Minister, the decision of Presidential Council for strategic development and national projects, Presidium of Council and subject to development in accordance with the decree;

2. Federal project, ensuring the achievement of goals, targets and additional indicators, the tasks of the national project and (or) achievement of other goals and targets, performing other tasks on behalf of and (or) the instruction of the President of the Russian Federation, the President of the Government of the Russian Federation, the Government of the Russian Federation, the decision of the Council, Presidium Council, order of the curator of the national project;

3. Departmental project - a project that ensures the achievement of goals and performance indicators of the Federal Executive authority;

4. Regional project - a project that ensures the achievement of the goals, indicators and results of a Federal project, the activities of which relate to the legally established powers of a subject of the Russian Federation, as well as to issues of local significance of municipalities located on the territory of the specified subject of the Russian Federation;

This Resolution does not apply to the national program: "Digital economy of the Russian Federation" and its constituent Federal projects.

From all this, we can conclude that tools have been created for the system management of national, Federal, departmental and regional projects for the customer. However, the project management system tools from the performers are completely absent.

\section{Discussion}

Analyzing this study, the authors came to the conclusion that the implementation and development of the project management system in public authorities is affected by certain factors of influence.

Figure 3 shows the factors that influence the implementation and effectiveness of project management systems. These main factors also had their place in the implementation and development efficiency of corporate project management systems in business. 


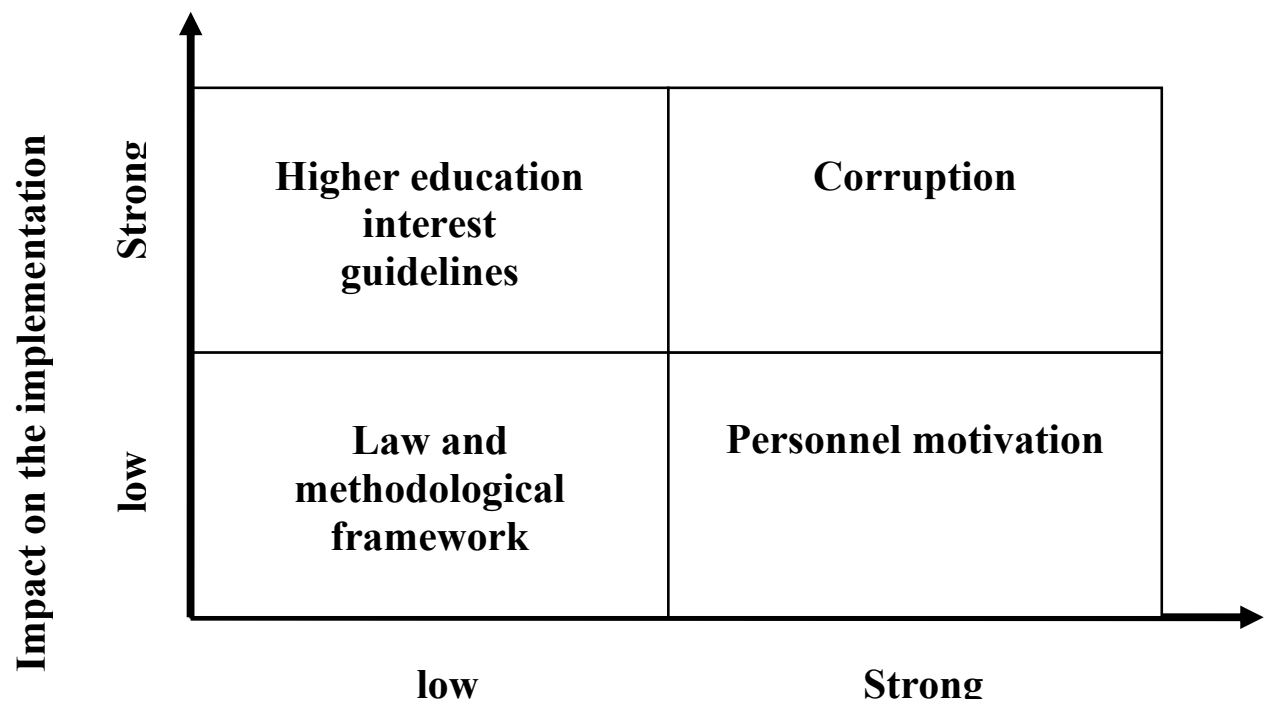

\section{Impact on development effectiveness}

Fig. 3. Matrix of influence on the implementation and effectiveness of project management systems development. [Compiled by the authors]

Analyzing the main factors influencing the implementation and effectiveness of project management systems, the authors developed recommendations for improving the project management system in public authorities, which should be implemented in four areas directly related to certain factors.

1. Development of organizational, regulatory and methodological framework for project management in public administration.

The organizational and regulatory framework includes the following elements:

- A system of regulatory documents that ensure the functioning of the multi-project project and program management system;

- A system of organizational decisions and structures necessary for effective project and program management;

- A system of measures to retrain and improve the skills of management personnel and Administration specialists in the field of project and program management.

The methodological framework is a set of documents describing the overall structure and approaches to implementing the project and program management system at all levels of government.

2. Creation of a system of effective motivation of personnel at all levels of public authorities.

To create an effective motivation system for project personnel, it is necessary to:

- Clearly define the goals and objectives of each employee's participation in the project (program) ;

- Familiarize project staff with tasks and tools that motivate each employee to perform tasks effectively.

The motivation system should be flexible [20]. When increasing the effectiveness of completed tasks that have affected the implementation of the project goals as a whole, the motivational component should be proportionally increased. All employees should be familiar with the motivational tools applied to them before involving them in the implementation of a particular project (program). 
3. The interest of senior management in project management is often directly related to the corruption component.

It is impossible to interest a Manager who regularly receives bribes in the implementation and development of project activities, since an effective project management system is an open system and implies transparency at all stages of project and program implementation. Such managers always sabotage the work of project personnel and find reasons for non-compliance with the instructions of President and Government of Russia to implement project management.

4. In order to fight corruption, a centralized, automated multi-project management system is proposed.

At the project (program) initiation stage, information, regardless of the level of the project and the authority initiating this project, should be sent to the Project office of Government of Russian Federation, which should be provided with a software product of the automated multi-project management system, which will receive daily all information about all projects initiated, planned, implemented and completed in Russian Federation, at all levels of government.

This will ensure that Government will have all the information about the entire project portfolio and respond quickly to all failures and deviations. Subordinate project management offices will no longer be able to hide their failures and write them off as unforeseen risks.

Monitoring the implementation and development of a multi-project management system should be sufficient. If the number of failures increases or decreases, the timing of the monitored parameters should change accordingly.

The functional structure has been significantly simplified, project management has essentially ended, and program and target management with elements of project management has returned.

In the future, we will definitely have to solve the issue of implementing and developing multi-project management, since resources are limited, and managers and curators of national and Federal projects are not directly responsible for project activities.

Consequently, Russian Government has not solved the problem of implementing multiproject management of national projects and programs.

The organization of the project management system in Russian Federation is proposed to be organized on the basis of the author's conceptual proposals. This system will be extended to all regions of Russian Federation at all levels in the future.

\section{References}

1. National Association of project management "SOVNET": http://www.sovnet.ru/about/history/ (2019) (In Russ.)

2. O.A. Markov, M. P. Loginov, Management Issues, 3 (52), 133-141 (2018) (In Russ.)

3. PMA project management Institute, https:// https://pmi.ru/about (2019)

4. V.I. Voropaev. Project Management. Moscow, ZAO "Project PRACTICE", 256 (2010) (In Russ.)

5. A.V. Polkovnikov, M. F. Dubovik. Full MBA course. Project management (Moscow, Olympus Business, 538) (2013) (In Russ.)

6. V. Bogdanov, Project Management. Corporate system - step by step (Moscow, Mann, Ivanov and Ferber, 2012) (In Russ.)

7. R.A. Nugaybekov, D.G. Maksin, A.V. Lyashuk. Corporate project management system: From methodology to practice, Moscow, Alpina Publisher, 2015) (In Russ.) 
8. G. Jia, X. Ni, Zh. Chen, B. Hong, Ch. Lin. Automation in Construction, 34, 56-66 (2013)

9. O.N. Safonova, E.A. Anchikhrov, Models, systems, networks in economics, technology, nature and society, 2 (14), 58-67 (2015) (In Russ.)

10. S. A. Kozhevnikov. Issues of territorial development, 5 (35), 1-17 (2016) (In Russ.)

11. K. Muszyńska. Procedia Computer Science, 126, 2184-2193 (2018)

12. Sh. Nikkhou, K. Taghizadeh, S. Hajiyakhchali. Procedia - Social and Behavioral Sciences, 226, 318-325 (2016)

13. J. Strojny. Proceedings-Social and Behavioral Sciences, 213, 787-793 (2015)

14. On Council under President of Russian Federation for strategic development and priority projects: Decree of President of Russian Federation No. 306 of 30 June 2016 URL: http://www.kremlin.ru/acts/bank/40945 (2016) (In Russ.)

15. M. Loginov, O. Markov, A. Ruchkin, International Transaction Journal of Engineering, Management, \& Applied Sciences \& Technologies, 16 (10), 1-13 (2019) DOI: 10.14456/ITJEMAST. 2019. 226

16. O. A. Markov, Economics and entrepreneurship, 4-2, 882-886 (2016) (In Russ.)

17. V. I. Dobrosotsky. Management Issues, 6 (49), 90-97 (2017)

18. O.A. Markov, M.P. Loginov, To the question of evaluating the effectiveness of the implementation of project management systems by business entities. Management Issues, 1 (44), 183-188 (2017) (In Russ.)

19. O. A. Markov, Bulletin of the Tajik national University, Series of socio-economic and social Sciences, 1, 12-18 (2020) (In Russ.)

20. R. T. Latypov, G. P. Maleikina, A. V. Ruchkin, Agrarian Bulletin of the Urals, 9(187), 75-90 (2019) (In Russ.) 